\title{
Review
}

\section{INOVASI TEKNOLOGI PEMANFAATAN LIMBAH KULIT BUAH KAKAO (Theobroma cacao L.) SEBAGAI PUPUK ORGANIK RAMAH LINGKUNGAN}

\author{
${ }^{1}$ Muh. Afif Juradi, ${ }^{2}$ Edi Tando, ${ }^{1}$ Ketut Suwitra \\ ${ }^{1}$ Balai Pengkajian Teknologi Pertanian Sulawesi Tengah \\ ${ }^{2}$ Balai Pengkajian Teknologi Pertanian Sulawesi Tenggara, Jalan Lasoso No 62 Sigi Biromaru \\ Email: afif.juradi@gmail.com
}

\begin{abstract}
ABSTRAK
Kakao (Theobroma cacao L.) di Indonesia suatu komoditas andalan pertanian, berperan sangat penting dalam perekonomian. produksi kakao di Indonesia tahun 2016 sebesar 656.817 ton. Produksi kakao nasional sebagian besar berasal dari Sulawesi $(63,8 \%)$ yang dihasilkan oleh mayoritas petani rakyat (smallholder). Tujuan penyusunan makalah yaitu untuk memberikan informasi tentang teknologi pemanfaatan limbah kulit buah kakao sebagai pupuk organik ramah lingkungan bagi tanaman sebagai alternatif dalam mengantisipasi tingginya harga maupun kelangkaan pupuk sintetis serta menjamin ketersediaan pupuk saat musim tanam, sehingga diharapkan dapat meningkatkan produktivitas dan pendapatan petani kakao. Inovasi pemanfaatan limbah kulit buah kakao pada pertanaman kakao berpotensi untuk diolah menjadi pupuk organik dalam bentuk kompos, berperan dalam memperbaiki sifat fisik tanah dan biologi tanah serta membantu penyerapan unsur hara penting bagi tanaman, sehingga dapat mendukung produktivitas kakao dan peningkatan pendapatn petani di masa datang.
\end{abstract}

Kata kunci: limbah kulit, buah kakao, pupuk organik, ramah lingkungan

\section{PENDAHULUAN}

Kakao(Theobroma cacao $\quad$ L.) di Indonesia merupakan suatu komoditas andalan pertanian, karena berperan penting dalam perekonomian nasional. Hal ini mengingat kakao selain sebagai penghasil devisa negara, juga telah menjadi sumber pendapatan petani maupun sebagai solusi dalam mewujudkan lapangan kerja baru serta mampu mendorong pertumbuhan usaha agrobisnis dan agroindustri serta pengembangan kawasan. Selanjutnya Indonesia sebagai negara pengekspor kakao ketiga terbesar didunia.

Menurut Ditjen Perkebunan (2016) bahwa produksi kakao di Indonesia sebesar 656.817 ton, capaian produksi tersebut menunjukkan bahwa produksi kakao terjadi penurunan sebesar 9,83 \% dibandingkan dengan capaian produksi di tahun 2014 sebesar 728.414 ton. Sementara Kamelia dan Fathurohman (2017) menyatakan bahwa produksi kakao Indonesia mengalami kenaikan sejak tahun 2009 sebesar 67,602 ton dan tahun 2010 sebesar 70,919 ton, selanjutnya apabila perbandingan limbah dari hasil panen kakao mencapai $75 \%$, maka kontribusi kulit buah kakao mencapai 53.190 ton pertahun. Selanjutnya, terdapat beberapa provinsi penghasil kakao terbesar di Indonesia, antara lain : Sulawesi Selatan (184.000 ton pertahun), Sulawesi Tengah (137.000 ton pertahun), Sulawesi Tenggara (111.000 ton pertahun), Sumatera Utara (51.000 ton pertahun), Lampung (26.046 ton pertahun), Kalimantan Timur (25.000 ton pertahun) dan daerah lainnya 122.000 ton pertahun. Luas areal kakao di Indonesia tercatat 959.000 ha, produksi 70.919 ton. Sementara, bobot buah kakao yang dipanen per ha akan diperoleh $6.200 \mathrm{~kg}$ kulit buah dan $2.178 \mathrm{~kg}$ biji basah (Statistik Perkebunan, 2010)

Secara nasional, produksi kakao dihasilkan oleh mayoritas petani rakyat (smallholder), sebagian besar berasal dari Sulawesi (63,8\%). Selanjutnya, Sulawesi Tengah secara nasional mampu memproduksi hingga $40 \%$ atau berkisar $500-600$ ribu ton setiap tahunnya dari total kakao nasional 
(Dewi, 2012), sementara masih terdapat peluang besar untuk mendapatkan nilai tambah dari produk olahan kakao, melalui limbah kulit buah kakao yang belum termanfaatkan. Menurut Rosniawati, et al., (2005) bahwa limbah ialah bahan terbuang, mempunyai dampak negatif, dapat mencemari lingkungan serta belum mempunyai nilai ekonomi. Salah satu cara untuk memanfaatkan sisa limbah pertanian ialah melalui pengolahan kulit buah kakao sebagai pupuk organik (kompos). Hal ini sesuai dengan Damanik, et al., (2013) bahwa limbah kulit buah kakao dapat diolah menjadi kompos untuk menambah bahan organik tanah.

Tujuan penyusunan makalah ialah untuk memberikan informasi tentang inovasi teknologi pemanfaatan limbah kulit buah kakao sebagai pupuk organik ramah lingkungan bagi tanaman sebagai alternatif dalam mengantisipasi tingginya harga maupun kelangkaan pupuk sintetis serta menjamin ketersediaan pupuk saat musim tanam, sehingga diharapkan dapat meningkatkan produktivitas dan pendapatan petani kakao.

\section{PEMBAHASAN}

\section{Potensi Kakao di Indonesia}

Keadaan di dalam negeri komoditi kakao terus mengalami peningkatan dan memiliki laju peningkatan yang cukup stabil berdasarkan data yang diperoleh tahun 2012. Negara Indonesia memiliki lahan perkebunan kakao yang cukup luas, sebesar 1.709.050 ha pada tahun 2012 mengalami peningkatan sebesar 2,01 \% dibandingkan tahun sebelumnya sebesar 1.677.254 ha. Persebaran lahan kakao (luas areal dan produksi) tahun 2013 disajikan pada Tabel 1.

Tabel 1. Persebaran lahan kakao, Tahun 2013.

\begin{tabular}{|c|c|c|c|}
\hline No. & Provinsi & Luas (ha) & Produksi (ton) \\
\hline 1 & Aceh & 106.211 & 28.329 \\
\hline 2 & Sumatera Utara & 76.486 & 31.789 \\
\hline 3 & Sumatera Barat & 150.319 & 58.740 \\
\hline 4 & Riau & 7.629 & 3.631 \\
\hline 5 & Kepulauan Riau & 9 & 1 \\
\hline 6 & Jambi & 2.082 & 512 \\
\hline 7 & Sumatera Selatan & 10.218 & 2.837 \\
\hline 8 & Kep. Bangka Belitung & 816 & 151 \\
\hline 9 & Bengkulu & 13.517 & 4.672 \\
\hline 10 & Lampung & 63.317 & 25.507 \\
\hline 11 & DKI Jakarta & 0 & 0 \\
\hline 12 & Jawa Barat & 8.963 & 2.427 \\
\hline 13 & Banten & 8.207 & 2.586 \\
\hline 14 & Jawa Tengah & 7.718 & 2.012 \\
\hline 15 & D.I Yogyakarta & 5.012 & 853 \\
\hline 16 & Jawa Timur & 65.432 & 30.364 \\
\hline 17 & Bali & 10.803 & 3.967 \\
\hline 18 & Nusa Tenggara Barat & 7.846 & 1.166 \\
\hline 19 & Nusa Tenggara Timur & 53.953 & 11.755 \\
\hline 20 & Kalimantan Barat & 11.754 & 2.032 \\
\hline 21 & Kalimantan Tengah & 929 & 205 \\
\hline 22 & Kalimantan Selatan & 757 & 74 \\
\hline 23 & Kalimantan Timur & 22.455 & 6.927 \\
\hline 24 & Sulawesi Utara & 17.723 & 4.434 \\
\hline 25 & Gorontalo & 13.462 & 3.826 \\
\hline 26 & Sulawesi Tengah & 284.125 & 149.071 \\
\hline 27 & Sulawesi Selatan & 254.622 & 117.672 \\
\hline 28 & Sulawesi Barat & 172.858 & 71.823 \\
\hline 29 & Sulawesi Tenggara & 255.347 & 120.243 \\
\hline 30 & Maluku & 27.666 & 8.555 \\
\hline
\end{tabular}




\begin{tabular}{llcc}
\hline 31 & Maluku Utara & 31.684 & 10.656 \\
32 & Papua & 32.946 & 9.768 \\
33 & Papua Barat & 15.746 & 4.277 \\
\hline
\end{tabular}

Sumber: Dirjen Perkebunan, 2014

Potensi Kakao di Sulawesi Tengah

Provinsi Sulawesi Tengah, memiliki potensi besar dalam pengembangan kakao. Hal ini nampak pada luas areal dan produksi kakao di Sulawesi Tengah disajikan pada Tabel 2.

Tabel 2.Luas Areal dan ProduksiKakaoMenurutKabupaten/Kota Tahun 2012 - 2016.

\begin{tabular}{llcc}
\hline No. & Kabupaten/Kota & Luas Lahan (ha) & Produksi (ton) \\
\hline 1 & Banggai Kepulauan & 6.756 & $1.869,01$ \\
2 & Banggai & 46.467 & $18.225,77$ \\
3 & Morowali & 6.116 & $4.767,10$ \\
4 & Poso & 39.209 & 25.639 \\
5 & Donggala & 30.164 & $19.335,99$ \\
6 & Toli-Toli & 21.154 & $11.260,95$ \\
7 & Buol & 11.541 & $5.719,31$ \\
8 & ParigiMoutong & 69.715 & $45.918,30$ \\
9 & TojoUna-Una & 13.891 & $8.814,50$ \\
10 & Sigi & 27.680 & 19.356 \\
11 & BanggaiLaut & 1.039 & 271,87 \\
12 & Morowali Utara & 14.661 & $7.498,08$ \\
13 & Kota Palu & 351 & 58,03 \\
& Sulawesi Tengah & & 168.733 \\
& 2016 & 289.194 & 146.507 \\
& 2015 & 288.986 & 208.485 \\
& 2014 & 291.445 & 195.846 \\
& 2013 & 284.125 & 181.523 \\
\hline
\end{tabular}

Sumber: BPS Sulawesi Tengah, 2017

Berdasarkan Tabel 2, menunjukkan bahwa pengembangan kakao di Sulawesi Tengah, dilakukan pada semua kabupaten, seperti: Parigi Moutong, Donggala, Poso, Morowali, Buol, Banggai, Toli-Toli dan Tojo Una-Una kecuali Kota Palu yang memiliki luas lahan terkecil. Namun, Kabupaten Parigi
Moutong memiliki luas lahan yang terbesar 62.543 ha, diikuti Kabupaten Donggala 37.817 ha dan Poso 31.473 ha. Selanjutnya komoditi kakao merupakan salah satu komoditas unggulan pada sektor perkebunan. Hal ini disajikan pada Tabel 3.

Tabel 3. Sektor Perkebunan Komoditas Unggulan Sektor Perkebunan Komoditi Kakao

\begin{tabular}{llcc}
\hline No. & \multicolumn{1}{c}{ Kabupaten } & Luas Lahan (ha) & Produksi (ton) \\
\hline 1. & Parigi Moutong & 62.543 & 66.746 \\
2. & Donggala & 37.817 & 36.631 \\
3. & Poso & 31.473 & 29.188 \\
4. & Morowali & 18.724 & 9.747 \\
5. & Buol & 13.536 & 11.605 \\
6. & Banggai & 12.206 & 7.361 \\
7. & Toli-Toli & 12.518 & 9.515 \\
8. & Banggai Kep & 7.007 & 2.982 \\
9. & Tojo Una-Una & 10.460 & 5.861 \\
10. & Kota Palu & 97 & 47 \\
& Provinsi & 206.381 & 179.683 \\
\hline
\end{tabular}

Sumber: BKPRS (Badan Kerjasama Pembangunan Regional Sulawesi, 2011) 


\section{Kandungan Unsur Hara Kulit Buah Kakao}

Agar dapat memenuhi syarat sebagai

pupuk organik, maka kandungan unsur hara

persyaratan teknis minimal. Hal ini dalam kulit buah kakao harus memenuhi

ditunjukkan pada Tabel 4.

Tabel 4. Persyaratan teknis minimal pupuk organik

\begin{tabular}{llccc}
\hline No. & Parameter & Satuan & $\begin{array}{c}\text { Persyaratan Mutu } \\
\text { Pupuk Organik Padat }\end{array}$ & $\begin{array}{c}\text { Hasil Analisis Kandungan } \\
\text { Kulit Buah Kakao }\end{array}$ \\
\hline 1. & C-Organik & $\%$ & $>12$ & 26.61 \\
2. & C/N ratio & $\%$ & $12-15$ & $<20$ \\
3. & pH & Ppm & 10 & 5.4 \\
4. & Kadar Total & $\%$ & $<6$ & 1.69 \\
& N & $\%$ & $<5$ & 0.34 \\
& P205 & & $<5$ & 2.81 \\
\hline
\end{tabular}

Sumber : Soplanit, 2012

Berdasarkan Tabel 4, menunjukkan bahwa persyaratan teknis minimal pupuk organik, harus memenuhi beberapa hal, antara lain : C-Organik (> 12), C/N (12-15), $\mathrm{pH}$ (10), Kadar Total N (<6\%), P205 (<5\%) dan $\mathrm{K} 20$ (<5\%)

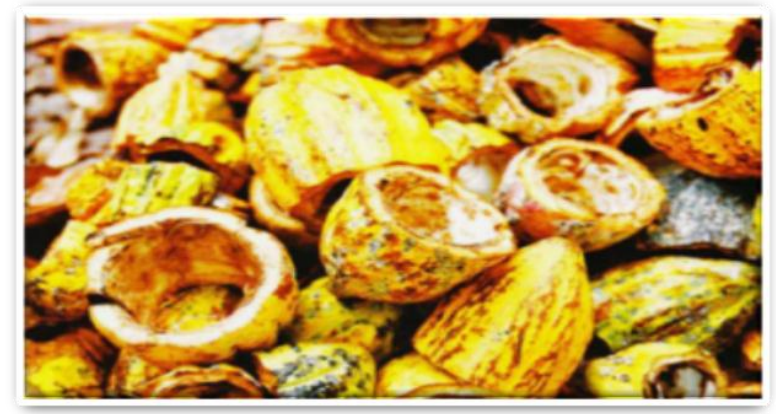

Gambar 1. Limbah Kulit Buah Kakao yang tidak termanfaatkan

Teknologi Pemanfaatan Limbah Kulit Buah Kakao sebagai Pupuk Organik Ramah Lingkungan

Keberadaan limbah kulit buah kakao yang melimpah dan tersedia sangat besar di lapangan, namun belum termanfaatkan secara optimal, sehingga dikhawatirkan menimbulkan masalah, jika tidak dilakukan pengelolaan dengan baik. Hasil penelitian Yelianti, et al. (2009) menunjukkan bahwa melalui pengelolaan limbah kulit kakao menjadi bahan organik dalam bentuk kompos terbukti secara optimal mampu memperbaiki sifat fisik tanah seperti struktur tanah menjadi lebih gembur serta membantu penyerapan unsur hara bagi tanaman (Yelianti, et al., 2009). Selanjutnya Sudirja, et al. (2005) menyatakan bahwa pemanfaatan kulit buah kakao dapat dilakukan dalam bentuk kompos, pakan ternak, produksi biogas dan sumber pektin. Aplikasi kulit buah kakao sebagai sumber bahan organik telah terbukti memiliki komposisi hara maupun senyawa yang berpotensi sebagai medium tumbuh tanaman. Kadar air untuk kakao lindak sekitar $86 \%$, dan kadar bahan organiknya sekitar 55,7\%. Kompos kulit buah kakao mempunyai pH 5,4, $\mathrm{N}$ total $1,30 \%, \mathrm{C}$ organik $33,71 \%, \mathrm{P} 2 \mathrm{O} 5$ 0,186\%, K2O 5,5\%, $\mathrm{CaO}$ 0,23\%, dan $\mathrm{MgO}$ $0,59 \%$. Kandungan hara mineral, terutama Kalium dan Nitrogen dalam kulit buah kakao cukup tinggi. Telah dilaporkan bahwa $61 \%$ dari total nutrien buah kakao tersimpan dalam kulit buah. Kandungan hara kompos yang dibuat dari kulit buah kakao adalah 1,81 \% N, 26,61 \% C-organik, 0,31\% P2O5, 6,08\% K2O, $1,22 \% \mathrm{CaO}, 1,37 \% \mathrm{MgO}$, dan $44,85 \mathrm{cmol} / \mathrm{kg}$ KTK. Menurut Isroi (1988) bahwa pemberian kompos kulit buah kakao dalam tanah mampu meningkatkan produksi tanaman hingga 19,48 
\%. Selanjutnya Ashadi (1988) menyatakan bahwa kulit buah kakao atau pod kakao merupakan komponen terbesar pada limbah buah kakao yaitu sebesar $75 \%$ dari total buah. Sementara, berdasarkan data produksi buah kakao yang mencapai 779,5 ribu ton, maka limbah pod kakao yang dihasilkan sebesar 584,6 ribu ton/tahun. Pupuk organik adalah pupuk yang berasal dari sisa-sisa organisme hidup. Pupuk organik yang sering digunakan adalah pupuk kandang dan kompos. Secara garis besar keuntungan yang diperoleh dengan memanfaatkan pupuk organik adalah mempengaruhi sifat fisik, kimia dan biologis tanah. Kompos adalah bahan organik mentah yang telah mengalami proses dekomposisi secara alami. Proses pengomposan memerlukan waktu yang panjang tergantung pada jenis biomassanya. Percepatan waktu pengomposan dapat ditempuh melalui kombinasi pencacahan bahan baku dan pemberian aktivator dekomposisi.Salah satu limbah pertanian yang baru sedikit dimanfaatkan adalah limbah dari perkebunan kakao yaitu kulit buah kakao.Opeke (1984), mengemukakan bahwa kulit buah kakao mengandung protein 9,69\%, glukosa $1,16 \%$, sukrosa $0,18 \%$, pektin $5,30 \%$, dan Theobromin 0,20\%.

\section{Peranan Bahan Organik Pada Tanaman}

Pemanfaatan bahan organik dalam tanah sebagai bahan esensial yang tidak dapat digantikan dengan bahan lain. Perananan bahan organik dalam tanah, mencakup perbaikan kesuburan fisik tanah (tekstur maupun struktur tanah) serta mendukung kehidupan mikro maupun makro organisme tanah serta sebagai sumber hara bagi tanaman. Sehingga aplikasi bahan organik ke dalam tanah memberikan dampak yang baik terhadap tanah dan media tumbuh tanaman. Respon positif akan diberikan tanaman, apabila media tumbuh tanaman mampu mendukung dalam pertumbuhan dan perkembangan tanaman. Menurut Brady (1990) bahwa hasil dekomposisi bahan organik dalam tanah dapat memberikan keuntungan bagi tanaman, yaitu tersedianya zat pengatur tumbuh tanaman seperti vitamin, asam amino, auksin dan giberelin. Bahan organik yang ditambahkan kedalam tanah mengandung karbon yang tinggi. Pengaturan jumah karbon didalam tanah meningkatkan produktivitas tanaman dan keberlanjutan umur tanaman karena dapat meningkatkan kesuburan tanah dan penggunaan hara secara efisien. Hasil penelitian mengenai bahan organik sudah banyak dilakukan dalam rangka peningkatan pertumbuhan tanaman. Bahan-bahan organik yang berasal dari sisa tanaman mengandung bermacam-macam unsur hara yang dapat dimanfaatkan kembali oleh tanaman jika telah terdekomposisi dengan baik, artinya bahwa bahan organik yang memiliki $\mathrm{C} / \mathrm{N}$ rendah lebih cepat menyediakan hara bagi tanaman, sedangkan apabila bahan organik memiliki $\mathrm{C} / \mathrm{N}$ yang tinggi akan mengimmobilisasi hara sehingga perlu dikomposkan terlebih dahulu, olehnya itu untuk mempercepat dekomposisi bahan organik yang memiliki $\mathrm{C} / \mathrm{N}$ yang tinggi sering ditambahkan aktivator seperti Promi atau yang lainnya. Selanjutnya bahan organik sebagai sumber koloid organik memiliki keunggulan, antara lain : kemampuan menyediakan hara makro dan mikro, menghelat unsur logam yang bersifat racun, meningkatkan kapasitas menahan air, meningkatkan KTK, sumber energi untuk aktivitas mikroorganisme tanah, serta memiliki sifat ramah lingkungan karena berasal dari residu mahkluk hidup dan limbah pertanian seperti kulit kakao, jerami padi. Upaya penambahan bahan organik sebagai upaya meningkatkan ketersediaan $\mathrm{N}$, memperbaiki kualitas tanah dan memperbaiki kesuburan tanah (Nariratihi et al., 2013)

\section{Peranan Kompos Kulit Buah Kakao Pada Tanah}

Limbah buah kakao dapat berupa daun guguran, kulit buah dan plasenta. Bobot kering daun gugur pada tanaman kakao meningkat. Potensi limbah kakao sebagai sumber bahan organik cukup besar. Limbah kakao mengandung sejumlah unsur hara penting. Jumlah unsur hara setara pupuk pada daun gugur dan kulit buah dengan produktivitas $1000 \mathrm{~kg}$ biji kering/ha yaitu 200 kg Urea, $75 \mathrm{~kg}$ TSP, $640 \mathrm{~kg} \mathrm{KCl}$, dan $210 \mathrm{~kg}$ Kiserit per ha. Jika limbah ini dimanfaatkan sebagai pupuk, petani telah ikut berperan membantu program pemerintah dalam hal 
penghematan penggunaan energi (pupuk buatan) dan pembangunan berwawasan lingkungan. Spillane (1995) dalam Astria dan Suntari (2017) menyatakan bahwa limbah kulit buah kakao dapat diolah dan dimanfaatkan sebagai sumber unsur hara tanaman melalui kompos, pakan ternak, produksi biogas dan sumber pectin, selanjutnya kulit buah kakao sebagai sumber bahan organik memiliki kandungan hara maupun senyawa potensial sebagai media tumbuh tanaman. Pupuk kompos merupakan pupuk yang berasal dari bahan-bahan organik yang ramah lingkungan. Kompos bermanfaat dalam memperbaiki sifat fisik, biologi dan kimia bagi tanah. selain itu kompos atau pupuk organik berperan dalam peningkatan bahan organik tanah dan sebagai buffer atau penyangga terhadap kelengasan (Wibowo, et al., 2014), Namun kendala dari penyediaan pupuk kompos ialah proses pengomposan yang cukup lama. Waktu pengomposan secara alami ialah sekitar 3-4 bulan. Artinya petani perlu menunggu selama itu untuk menggunakan pupuk tersebut. Oleh karena itu perlu menggunakan bantuan mikroorganisme sebagai dekomposer untuk mempercepat pengomposan.Pemanfaatan mikrooranisme sebagai dekomposer untuk mempercepat pengomposan merupakan salah satu alternatif yang dapat digunakan. Selain itu untuk memperolehnya cukup mudah dapat menggunakan bahan yang mudah ditemukan. Bahan-bahan yang digunakan kemudian dimanfaatkan untuk membuat mol yang berfungsi sebagai starter untuk dekomposisi bahan organik. Hal ini diharapkan mampu mempercepat pembusukan bahan organik. Hingga pupuk kompos dapat digunakan.Penyediaan pupuk kompos tentu membutuhkan waktu yang tidak terlalu lama, sehingga petani enggan dalam memanfaatkannya.

Beberapa upaya telah dilakukan untuk memperbaiki sifat Ultisol melalui pengapuran untuk menaikkan $\mathrm{pH}$ tanah, penambahan bahan organik untuk memperbaiki sifat fisika, kimia, dan biologi tanah, serta pemupukan, sementara pemberian kompos sering dilakukan sebagai upaya memperbaiki kandungan bahan organik tanah. Hasil penelitian Shalsabila et al., (2017) menunjukkan bahwa semakin tinggi aplikasi dosis biochar kulit kakao pada tanah Ultisol, dapat meningkatkan produksi tanaman jagung, namun untuk musim tanam pertama, dosis biochar kulit buah kakao belum mampu mempengaruhi nilai kemantapan agregat tanah. Indeks kemantapan agregat paling tinggi terdapat $15 \mathrm{t}$ ha-1 biochar kulit buah kakao yaitu sebesar 130,12. Produksi tanaman jagung paling tinggi terdapat pada perlakuan D4 (40 ton ha ${ }^{-1}$ biochar kulit buah kakao) dengan berat biji kering 3,95 $\mathrm{t}$ ha-1, berat biomassa kering 1,82 $\mathrm{t}$ ha-1, berat bonggol kering 2,28 $\mathrm{t}$.

\section{Prosedur Pengomposan Kulit Buah Kakao}

Pembuatan kompos dari limbah pertanian, prinsipnyaharus mudah, murah, dan cepat. Aktivator yang digunakan, meliputi promi atau orgadec untuk mempercepat proses dekomposisi sampai hasil akhirnya. Lebih jelasnya dapat di lihat pada gambar 2.

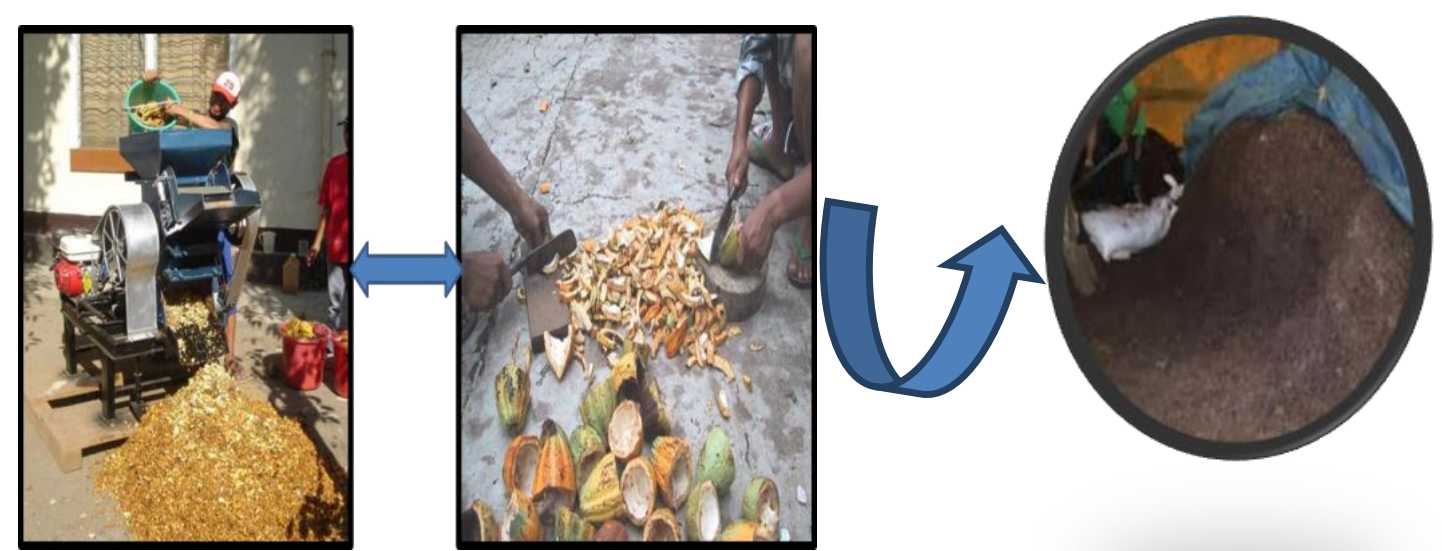

Gambar 2. Proses pembuatan limbah kulit buah kakao menjadi pupuk organik (pupuk kompos) 
Ada pun tahapan pembutan limbah kulit buah kakao menjadi kompos, yaitu : 1) Memperkecil ukuran bahan. Untuk memperkecil ukuran bahan dapat dilakukan dengan menggunakan parang atau dengan mesin pencacah, 2) Menyiapkan aktivator pengomposan. Aktivator (Orgadec atau Promi) dilarutkan ke dalam airsesuai dosis yang dibutuhkan, 3) Melakukan pemasangan cetakan, 4) Memasukkan bahan ke dalam cetakan selapis demi selapis. Tinggi lapisan kurang lebih seperlima dari tinggi cetakan, 5) Menginjak-injak bahan, agar memadat, kemudian dilakukan penyiraman dengan aktivator pengomposan, 6) Membuka cetakan dan menutup tumpukan kulit buah kakao dengan plastik setelah cetakan penuh, 7) Mengikat tumpukan dengan tali, selanjutnya diinkubasikan selama 1,5 sampai 2 bulan. Agar proses pengomposan dapat berjalan dengan baik, perlu dilakukan pengamatan secara teratur. Pengamatan dapat dilakukan seminggu sekali hingga kompos siap digunakan. Pengamatan secara visual dapat dilakukan dengan menggunakan peralatan sederhana. Pengamatan meliputi: suhu, kelembaban, penurunan volume, dan kenampakan kompos. Membuka plastik penutup kompos dan meraba tumpukan kompos hingga bagian dalam. Seharusnya dalam waktu satu dua hari setelah pembuatan kompos, suhu akan meningkat dengan cepat. Peningkatan suhu dapat mencapai $70^{\circ} \mathrm{C}$ dan dapat berlangsung beberapa minggu. Memeriksa juga kadar air/kelembaban kompos hingga bagian dalam kompos. Kompos yang baik akan terasa lembab namun tidak terlalu basah. Sejalan dengan proses penguraian bahan organik menjadi kompos akan terjadi penyusutan volume kompos. Penyusutan volume ini dapat mencapi setengah dari volume semula. Apabila selama proses pengomposan tidak terjadi penyusutan volume, kemungkinan proses pengomposan tidak berjalan dengan baik. Amati pula perubahan warna yang terjadi pada bahan baku kompos. Biasanya warna akan berubah menjadi coklat kehitam-hitaman. Seringkali jamur juga ditemukan tumbuh subur di atas tumpukan kompos. Proses pengomposan yang dipraktekan ini adalah pengomposan aerobik, seharusnya tidak muncul bau menyengat seperti bau air comberan pada saat proses pengomposan. Apabila muncul bau yang menyengat kemungkinan proses pengomposan berjalan anaerob.

\section{Prospek Pengembangan Limbah Kulit Buah Kakao sebagai Pupuk Organik Ramah Lingkungan}

Limbah kakao memiliki potensi besar untuk dikembangkan di masa datang, menggingat ketersediaan limbah kakao saat panen yang besar, namun belum termanfaatkan secara ekonomis, sementara beberapa tahun terakhir ini, adanya kebijakan pemerintah secara bertahap telah mengurangi subsidi pupuk Urea, TSP dan $\mathrm{KCl}$ bagi petani, hal ini menyebabkan peningkatan harga pupuk dan terjadi kelangkaan. Kondisi ini berdampak berkurangnya penggunaan pupuk pada usahatani kakao, akibatnya produksi mengalami penurunan. Selanjutnya, dalam upaya mempertahankan dan memperbaiki kondisi kesuburan tanah agar tetap subur dan produktif, maka diperlukan suatu upay, midalnya melalui pemanfaatan sumber daya lokal secara optimal sebagai pupuk organik. Pemanfaatan bahan organik potensial yang ada di pertanaman kakao, meliputi limbah kulit buah kakao, dedaunan yang gugur maupun plasenta/pulpa, merupakan suatu alternatif sebagai pupuk organik dan selama ini belum diketahui dan dimanfaatkan petani kakao. Pemanfatan limbah pertanian sebagai pupuk organik ialah melalui pengomposan, dengan bantuan mikroorganisme lokal yang memiliki kemampuan dalam membantu proses dekomposisi bahan organik, sehingga dapat dijadikan sebagai kompos sebagai pupuk organik dan siap diaplikasikan ke tanaman. Dengan demikian kebutuhan pupuk pada tanaman kakao dapat dipenuhi dari pemanfaatan limbah tanaman kakao, sehingga diharapkan mampu meningkatkan produksi dan memperbaiki kualitas kakao (Nappu, B. 2013).

Menurut Mulato et. al., (2005) bahwa kulit buah kakao ialah salah satu jenis limbah hasil tanaman perkebunan yang memiliki potensi besar dan komponen terbesar yaitu 70\% dari berat buah kakao masak. Namun, 
kulit buah kakao belum dimanfaatkan secara optimal. Kulit buah kakao merupakan salah satu limbah dari perkebunan kakao. Apabila tidak dimanfaatkan dapat merupakan masalah lingkungan di sekitar perkebunan, kulit buah kakao dijadikan kompos yang dapat digunakan sebagai pupuk organik yang dapat digunakan sebagai suplemen ataupun pengganti pupuk kimia (anorganik). Penggunaan kompos ini dapat digunakan pada tanaman hortikultura (sayur-sayuran) sebagai pengganti penggunaan pupuk sintetik dalam jumlah yang besar. Sebagai contoh di Sulawesi Selatan luas tanaman kakao di Sulawesi Selatan sekitar 200.000 ha, dengan hasil $1.000 \mathrm{~kg} / \mathrm{ha}$ dan pemanfaatan limbah kakao setara pupuk sekitar $1000 \mathrm{~kg}$, sementara harga pupuk diperkirakan $\mathrm{Rp}$ $2.500 / \mathrm{kg}$, maka jumlah penghematan atas penggunaan limbah kakao ditaksir sekitar Rp 500 Milyar/tahun, suatu jumlah yang cukup banyak. Dengan demikian pendapatan petani akan meningkat $\mathrm{Rp} 2.500 .000 /$ ha, lahan pertanaman kakao tetap terjamin kesuburannya dan produksi kakao diharapkan meningkat dan stabil.

\section{KESIMPULAN}

Inovasi pemanfaatan limbah kulit buah kakao pada pertanaman kakao berpotensi untuk diolah menjadi pupuk organik dalam bentuk kompos, berperan dalam memperbaiki sifat fisik tanah dan biologi tanah serta membantu penyerapan unsur hara penting bagi tanaman, sehingga dapat mendukung produktivitas kakao dan peningkatan pendapatn petani di masa datang.

\section{DAFTAR PUSTAKA}

Astria, P. dan Suntari, R. 2017. Aplikasi Urea dan Kompos Kulit Kakau Untuk Meningkatkan Ketersediaan dan Serapan N, P, K serta Produksi Tanaman Sayuran Sawi padalnceptisol Tulungrejo, Batu. Jurnal Tanah dan Sumberdaya Lahan. 4 (1) : 453-461.

Damanik, H.F., Ginting, J., Irsal. 2013. Respon Pertumbuhan Bibit Kakao (Theobroma cacao L.) Terhadap Beberapa Komposisi Kompos Kulit Buah Kakao dengan Subsoil Ultisol dan Pupuk Daun. Jurnal Agroekoteknologi. 2 (1) : 162-171.

Dewi, N. 2012. Analisis Peluang Pilihan Kelembagaan Pemasaran Kakao di Provinsi Sulawesi Tengah. Indonesian Journal of Agricultural Economics (IJAE). 3 (1) : 1-12.

Direktorat Jenderal Perkebunan, 2014. Statistik Perkebunan Indonesia Komoditas Kakao 2013-2015. Direktorat Jenderal Perkebunan. 58 hal.

Isroi, 2007. Pengomposan Limbah Kakao. Materi disampaikan pada Acara Pelatihan TOT Budidaya Kopi dan Kakao Staf BPTP di Pusat Penelitian Kopi dan Kakao. Peneliti pada Balai Penelitian Bioteknoogi Perkebunan Indonesia. Jember, 25-30 Juni 2007

Kamelia, M. dan Fathurohman. 2017. Pemanfaatan Kulit Buah Kakao Fermentasi Fermentasi sebagai Alternatif Bahan Pakan Nabati serta Pengaruhnya Terhadap Pertumbuhan Ternak Entok (Cairina muschata). BIOSFER Jurnal Tadris Pendidikan Biologi. 8 (1) : 66-77.

Nariratihi, I. Damanik, MMB dan Sitanggang, G. 2013. Ketersediaan Nitrogen Pada Tiga Jenis Tanah Akibat Pemberian Tiga Bahan Organik dan Serapannya pada Tanaman Jagung. Jurnal Online Agroekoteknologi. $1(3): 479$ - 488.

Puastuti, W., dan IWR Suzana. 2014. Potensi dan Pemanfaatan Kulit Buah Kakao Sebagai Pakan Alternatif Ternak Ruminansia. Wartazoa 24 (3) :151159.

Rosniawati, S., Dewi, A., I., R. Suherman, C. $2005 . \quad$ Laporan Penelitian. Pemanfaatan Limbah Kulit Buah Kakao Sebagai Kompos pada Pertumbuhan Bibit Kakao (theobroma cacao I.) Kultivar upper amazone hybrid. Dibiayai oleh Dana Penelitian Dosen DIPA PNBP. Lembaga Penelitian Universitas Padjajaran. Bandung. 
Shalsabila, F. Prijono, S. dan Kusuma, Z. 2017. Pengaruh Aplikasi Biochar Kulit Kakao terhadap Kemantapan Agregat dan Produksi Tanaman Jagung pada Ultisol Lampung Timur. Jurnal Tanah dan Sumberdaya Lahan. 4 (1) : 473-480.

Soplanit, A. 2012. Kajian Penerapan Teknologi Berbasis LEISA Melalui Tumpangsari Wortel dengan Sayuran Lainnya di Dataran Tinggi Papua. Prosiding Seminar Nasional Pekan Inovasi Teknologi Hortikultura Nasional; Penerapan Inovasi Teknologi Hortikultura dalam Mendukung Pembangunan Hortikultura yang Berdaya Saing dan Berbasis Sumberdaya Genetik Lokal. Hal 156162.

Sri Mulato, S. Widyantomo, Misnawati dan E. Suharyanto. 2005. Petunjuk Teknis Pengolahan Produk Primer dan Sekunder Kakao. Jurnal Universitas Jember.

Sudirja, R., Solihin, M.A., Rosniawaty, S. 2005. Pengaruh Kompos Kulit Buah Kakao dan Kascing Terhadap Perbaikan Beberapa Sifat Kimia Fluventic Eutrudepts. Dibiayai oleh Dana Penelitian Dosen DIPA PNBP. Lembaga Penelitian Universitas Padjajaran. Bandung.

Wibowo, A. Wijayanti, H. danHudaidah, S. 2014. Pemanfaatan Kompos Kulit Kakao (Theobroma cacaoL)Untuk Budidaya Daphniasp. e-Jurnal Rekayasadan Teknologi Budidaya Perairan. 2 (2) : 227 - 232.

Yanqoritha, N. 2013.Optimasi Aktivator dalam Pembuatan Kompos Organik dari Limbah Kakao. Majalah Ilmiah Mektek. Jurusan Teknik Kimia Fakultas Teknik Industri Institut Teknologi Medan, Sumatera Utara.

Yelianti, U. Kasli, M. Kasim. E. dan Husin, F. 2009. Kualitas Pupuk Organik Hasil Dekomposisi Beberapa Bahan Organik dengan Dekomposernya. Jurnal Akta Agrosia. 12 (1) : $1-7$. 